\title{
Double-entry analysis system (DEAS) for comprehensive quality evaluation of websites: case study in the tourism sector
}

\author{
Carles Sanabre; Rafael Pedraza-Jiménez; Sara Vinyals-Mirabent
}

Nota: Este artículo se puede leer en español en:

https://recyt.fecyt.es/index.php/EPI/article/view/73831

How to cite this article:

Sanabre, Carles; Pedraza-Jiménez, Rafael; Vinyals-Mirabent, Sara (2020). "Double-entry analysis system (DEAS) for comprehensive quality evaluation of websites: case study in the tourism sector". Profesional de la información, v. 29, n. 4, e290432.

https://doi.org/10.3145/epi.2020.jul.32

Article received on 31 July 2019

Final acceptance: 13 March 2020

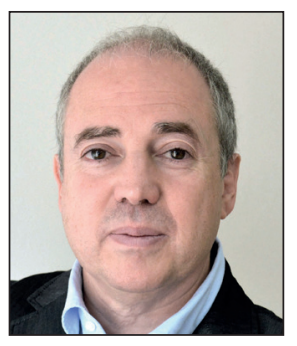

Carles Sanabre $\bowtie$

https://orcid.org/0000-0001-7711-8005

Universitat Pompeu Fabra

Departament de Comunicació

Roc Boronat, 138

08018 Barcelona, Spain

carles.sanabre@upf.edu

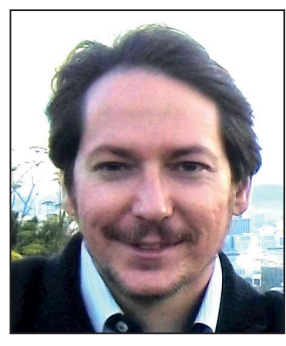

Rafael Pedraza-Jiménez

https://orcid.org/0000-0002-6918-6910

Universitat Pompeu Fabra

Departament de Comunicació

Roc Boronat, 138

08018 Barcelona, Spain

rafael.pedraza@upf.edu

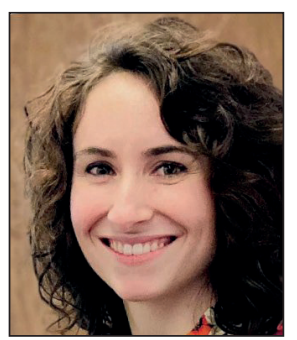

Sara Vinyals-Mirabent

https://orcid.org/0000-0001-7120-6039

Universitat Pompeu Fabra

Departament de Comunicació

Roc Boronat, 138

08018 Barcelona, Spain

sara.vinyals@upf.edu

\begin{abstract}
A new analysis system for evaluating website quality is presented. It is characterized by its ability to interrelate and evaluate both technical and strategic aspects of a website. It is based on the premise that, while the technical aspects that govern the operation and functionality have a great impact on the quality of a website, they do not guarantee its success on their own. This approach differs from those commonly adopted in analysis systems, since until now most of them have been developed by adopting a predominantly operational or functional view.
\end{abstract}

\section{Keywords}

Websites; Website quality; Website evaluation; Web quality index; Strategic web quality; Technical web quality; Comprehensive web quality; Analysis systems; Methods; Web strategy; Tourist websites; E-tourism. 


\section{Introduction}

A website is a dynamic entity that evolves and needs to be periodically reviewed using analysis programs or systems to guarantee its quality (Sanabre, 2015). Currently, there are many, very different systems for such analysis (Codina, 2006; Pedraza-Jiménez; Codina; Guallar, 2016; Hernández; Jiménez; Martín, 2009; Jiménez-Iglesias; Pérez-Montoro; Sánchez-Gómez, 2017). These proposals adopt very different approaches which vary depending on the elements that their authors consider key in evaluating and determining the quality of a website. In some cases, these proposals include their own quality indices, as is the case of the Web site evaluation index, which mainly measures the quality of the following aspects: navigation, content, languages, privacy, and security (Xanthidis; Argyrides; Nicholas, 2009).

Among these systems, those that focus their analysis on the content or technical characteristics of the website are more predominant (Codina, 2006). Others, of a more generic nature, propose quality models designed for use in both software and web analysis (Fogli; Guida, 2015). Some of these systems analyze aspects such as accessibility, usability, impact, and utility, taking into consideration the EQ-EVAL and QM-U methodologies (Fogli; Guida, 2018). In addition, there are highly specialized analysis systems that focus on specific aspects, such as visibility in search engines (Lopezosa; Codina; Rovira, 2019).

As a whole, all these tools coexist with analysis systems of a strategic nature, although the latter remain very scarce. Consequently, when talking about the quality of a website, it is often only its technical aspects that are referred to. This makes it possible for a website that exhibits high technical quality to be evaluated as correct or even excellent, while it may lack a well-thought-out business logic and be doomed to fail due to a lack of adequate strategic conception (Sanabre; Pedraza-Jiménez; Codina, 2018).

Unlike traditional approaches, our proposal begins with the premise that it is not possible to adequately evaluate the quality of a website by only taking into consideration its technical and functional aspects. Furthermore, we consider that the technical and functional aspects must be aligned with the strategic aspects to guarantee that it adequately fulfills its function.

This work confirms and formalizes this interrelation by proposing a double-entry system for analyzing website quality. That is to say, a system that, on the one hand, makes it possible to define and analyze the strategy and to determine which technical aspects will have the greatest impact on its achievement. On the other hand, it allows the technical aspects to be directly evaluated, and to identify the extent to which they favor or condition the success of the website's mission.

The current work also aims to apply and test the new proposed analysis system. To this end, various official websites of European tourist destinations are evaluated using it.

\section{The website in the tourism sector and its evaluation}

Nowadays, the internet is the place where tourists seek information about destinations, the space where they make their decisions, the tool they use to organize their trip, and even the place where they buy tourist products (European Commission, 2017; Patkose; Stokes; Cook, 2004; Xiang; Wang; O'Leary; Fesenmaier, 2014). Thus, online communication and websites in particular have become a new channel for tourism consumption (Buhalis; Law, 2008; Law; Qi; Buhalis, 2010; Luna-Nevarez; Hyman, 2012; Park; Gretzel, 2007), and with this, researchers in the field of communication have been paying increasing attention to the characteristics of these websites and their possibilities (Standing; Tang-Taye; Boyer, 2014; Sun et al., 2017).

In particular, official websites, such as those of organizational communication entities for a destination, have attracted great attention from researchers due to their influence on the attitude and decision-making process of tourists (Tang; Jang, 2011). In this sense, Luna-Nevarez and Hyman (2012) describe the official destination site as its representative on the internet, reflecting everything about the destination and what it offers to tourists.

As a consequence of the relevance that these websites have acquired for the institutions that administer them, i.e., destination marketing organizations (DMOs), it is essential to ensure their quality (Fernández-Cavia et al., 2013). For DMOs, it is vital to have high-quality official websites, at both a strategic and operational level, that satisfy the informational needs of potential tourists and discourage their users from turning to alternative sources of information (Chias, 2005). For this, it is not enough nowadays to create official websites, but instead it is imperative that DMOs invest constant effort in their evaluation and optimization (Morrison, 2013).

There are various evaluation systems that allow for the improvement of websites (Ip; Law; Lee, 2011) and have been applied in research studies to judge the value, usefulness, or functionality of a product according to certain criteria (Guallar; Abadal; Codina, 2013). Such evaluative proposals may vary depending on the elements that their authors consider key to the quality of a website and on the methodological approach. In tourism, there are five predominant evaluative approaches:

- Counting

- Automation

- Numerical computation

- User experience

- Combinations of methods for the analysis of optimal characteristics (Law; Qi; Buhalis, 2010) 
In this way, in relation to the quality of tourist websites, we can verify once again that technical approaches are predominant. Therefore, there is a need for a holistic approach that simultaneously takes into account operational as well as strategic quality (Auer; Petrovic, 2004; Sanabre; Vinyals-Mirabent; Pedraza-Jiménez, 2019). Although such evaluation varies between the perspective of the user and the issuer (Auer; Petrovic, 2004), we find ourselves in a context where DMOs are increasingly interested in

"knowing whether their website has high-quality elements, beyond evidence for the quality of the content or the showiness of the design" (Codina, 2000).

\section{The website as a strategic tool}

The ideation of websites (Pedraza-Jiménez et al., 2013) has been approached using different methodologies. There are classic (but still current) approaches, which are characterized by emerging prior to the emergence of the social web. One of the first and most important, due to its enormous influence, is that by Nielsen $(1994,1999)$ which focuses on usability.

Another of the best-known proposals is Garrett's (2011) general scheme, whose foundations mainly lie at an operational or technical level. In addition, it also refers to strategic aspects, to indicate the need to establish the objectives of the website at an initial phase, prior to development. However, it does not explain how to define them. Garrett's main contribution is to integrate almost all the disciplines related to web design (such as user experience design, interface design, or development implementation) without requiring excessive dependencies between them.

On the other hand, Olsen (2003) presents a model with elements that, without being related, consider some basic strategic aspects of the website. Another important reference is Dalton (2007), who proposes a web ideation system that emphasizes the needs of the users and the business objectives of the organization. Rosenfeld and Morville (2006) speak along the same lines, pointing out the importance of determining which strategies a business pursues before defining the information architecture of its website. However, those authors do not define techniques or tools to establish this relationship.

For their part, Hernández, Jiménez and Martín (2009), based on an extensive bibliographic review, conclude that the key aspects of web design are:

- Searchability

- Access speed

- Usability

- Content quality

- Interactivity

- Transactional capacity.

Other proposals, such as that of Kaur and Gupta (2014) in their Web quality model cube, consider that the quality of a website resides in its technical aspects and in content. In this case, usability is considered a key factor in quality. The importance of this factor was also recognized by Qayyum and Rafiq (2016), but those authors consider that this factor, by itself, is insufficient to evaluate the quality of a website globally.

Along the same lines, the work of Piñeiro-Naval, Igartua, and Marañón (2017) on the municipal websites of Spain deserves attention. In their study they consider web design to be

"a complex concept, formed by the principles of visual appearance, information architecture, and usability, which represent the core elements to be evaluated in the planning and development of a website"

However, in this case as well, explicit value is not given to the strategy as a core element for success.

In other cases (Pérez-Montoro; Codina, 2010), the use of wireframes or mockups is proposed to address this complexity and to transfer the idea of those responsible for the website to the designer. However, when using this procedure, one can make the mistake of neglecting an adequate strategic design. This problem has already been verified by authors such as González-López, Bañegil-Palacios, and Buenadicha-Mateos (2013), who point out the need for organizations to evaluate the online strategy related to their website. In fact, they propose an index that measures a part of the web strategy related to the online headquarters, the so-called Quantitative web quality index. However, the same authors conclude that their index

"should be considered as part of a larger index that brings together more concepts related to the organization's web strategy"

Therefore, they do not approach the study of the strategy of the site from a global perspective. Along the same lines, we highlight the ideas of Fisher, Craig, and Bentley (2007), who associate the concept of "site strategy maturity" with its quality.

If we focus on websites of tourist destinations, we also find various studies that have focused on the analysis of their quality, but these studies still do not address the problem of the global strategy. This is the case of the proposal by Tran and Yan (2014), who elaborate a model for DMOs that mainly focuses on the analysis of the technical aspects of the website, such as its SEO or transactional capacity. 
The study by Jayaram and Kamal (2016) is also interesting, as they propose a conceptual model that aims to expand knowledge about the role of interactivity on the web. According to their work, the more interactive a hotel website, the higher its value as perceived by the customer. They thus highlight the relevance of interactivity as a value for the user.

Finally, the proposal by Mandal, Roy, and Raju (2017) should also be mentioned. Based on their study of tourist websites, those authors contribute the new concept of website resilience, which they define as the customer's perception of a website's features or capabilities in terms of restoring its operations and functionality when faced with any type of disruption, for example, after a technical failure. They also present a model focused on the aspects of analytics, resilience, agility, attractiveness, and intention to revisit. This model considers strategic aspects, such as the intentionality of the user or the design, although in a very incomplete fashion.

This literature review on web quality thus confirms that the strategic aspects of the website are recognized as essential factors for the success of its mission. Despite this, studies that identify the incorporation of the strategy into the analysis process remain scarce, nor have any works that study how the strategic and technical aspects condition and influence each other been identified. In this regard, only the Website canvas model analysis and strategic ideation system has been identified (Sanabre, 2015; Sanabre; Pedraza-Jiménez; Codina, 2018).

\section{The website as an operational tool}

In recent decades, many researchers have worked towards the development of useful methodologies for evaluating the operation of official tourism websites. Several studies have focused on the evaluation of characteristics such as quality and information (Inversini; Cantoni; De-Pietro, 2014; Law; Bai, 2008; Rodríguez-Molina; Frías-Jamilena; Castañeda-García, 2015), technical elements (Dedeke, 2016; Kang; Kim, 2006), design (Lee; Gretzel, 2012; Vinyals-Mirabent, 2014), and impact and general operation (Dickinger; Stangl, 2013).

Despite all these studies, the debate regarding which characteristics a holistic web evaluation model should contain remains open (Law; Qi; Buhalis, 2010). The multidimensional nature that characterizes these systems for website analysis poses a challenge for their creation (Cho; Sung, 2012; Fernández-Cavia et al., 2014). Currently, there are five major areas of web evaluation: informational, technical, persuasive, relational, and strategic, although only the first four have generated an abundant scientific literature so far.

Many researchers have included the technical dimension in their evaluation proposals (Ip; Law; Lee, 2011). Characteristics such as usability, accessibility, or the architecture of the site are key elements that determine its quality at a technical level (Li; Wang, 2010; Morrison, 2013). In addition, factors such as positioning (Rovira et al., 2010) or site security (Park; Gretzel, 2007) have been added more recently to the set of technical features that determine web quality. However, due to the great attention that the technical characteristics have garnered, the communicative and discursive characteristics have sometimes been neglected (Inversini; Cantoni; De-Pietro, 2014; Opoku; Abratt; Pitt, 2006; Opoku, 2009).

This can be clearly seen if we return to the context of the official websites of tourist destinations. The quality of the information they offer is crucial for the perception of the destination by the user (Tang; Jang; Morrison, 2012). In fact, several authors point to the importance of evaluating not only the quality or quantity of information offered, but also its persuasive capacity and ability to attract tourists (Fernández-Cavia et al., 2014; Park; Gretzel, 2007). We found proposals that consider visual appeal, the effectiveness of marketing techniques (Morrison, 2013), or the ability of the discourse to promote marketing actions at the destination (Fernández-Cavia et al., 2014; Li; Wang, 2010).

Tourism experts agree with web quality experts that the evaluation of the interactive capabilities of the site is essential for its operational functioning (Contreras, 2010; Li; Wang, 2010). In this sense, customization options based on the profile of each tourist (Pike, 2012), or functions that enable the tourist to co-create the official discourse of the destination (Therkelsen, 2015), are some key indicators for the web evaluation at this level.

We thus conclude that advances in evaluation systems for tourist websites have been disparate and complementary, and although analysis tools exist to facilitate an operational evaluation of the official websites of destinations, they focus on their more technical aspects (Pedraza-Jiménez; Codina; Guallar, 2016), while in this domain there is still a lack of analysis systems that take the strategic dimension into consideration.

\section{Objectives}

This work has three objectives:

I. To present a new analysis system for the comprehensive evaluation of web quality.

II. To propose an index that allows for the evaluation and comparison of the quality of the websites evaluated using this system.

III. To apply this system to a case study, specifically tourism websites, to test its operation.

To achieve these objectives, it is necessary to propose a system capable of identifying the strategic aspects that guarantee the success of a website's mission. Likewise, the system must identify the technical characteristics of an operational and functional nature that guarantee the correct functioning of the site. Finally, the system must identify how the strategic aspects are related to these technical characteristics of the website to detect their interdependencies. 


\section{Methodology}

\subsection{Bibliographic review}

A literature review was carried out using the Web of Science and Scopus databases, as well as the academic search engine Google Scholar. Searches were limited to the period between 2000 to 2019. The initial search terms, which were extended as relevant results were found, were:

("website quality" OR "web site quality" OR "web quality") AND (assessment OR evaluation)

"website strategy" OR "web site strategy" OR "web strategy"

("website quality" OR "web site quality" OR "web quality") AND (assessment OR evaluation) AND (strateg*)

("website quality" OR "web site quality" OR "web quality") AND (assessment OR evaluation) AND (tourism OR destination)

In this way, most of the systems and proposals mentioned above were identified, revealing a gap regarding the strategic precision of the website, an aspect that has been incorporated into and is central to the current proposal.

\subsection{Analysis systems}

Two analysis systems were selected to serve as a basis for the formalization of this new proposal. The current authors participated in the creation of these systems, and their operation has already been tested. One of them, called the Website canvas model (Sanabre, 2015; Sanabre; Pedraza-Jiménez; Codina, 2018), is useful for the analysis and specification of the strategy of a website. The other is the Tourism website assessment system (TWAS, or Sistema de análisis de sitios web turísticos (SAST) in Spanish) (Fernández-Cavia; Vinyals-Mirabent; López-Pérez, 2013) used for the evaluation of operational and functional characteristics.

The Website canvas model (WSCM) identifies 14 key aspects in the strategy of a website, representing them in a synthesized way on a canvas or model (Figure 1). It takes the Business canvas model by Osterwalder and Pigneur (2010) as a reference, modifying it for application in the context of the creation, design, and development of websites (Sanabre, 2015; Sanabre; Pedraza-Jiménez; Codina, 2018).

Meanwhile, the Tourism website assessment system (TWAS) is a system to evaluate the technical quality of a website, consisting of 12 parameters and 127 indicators (Table 1). The parameters refer to general aspects of the website, such as its content, navigation, usability, etc. These parameters are made up of a set of indicators, each of which allows for the evaluation of a specific aspect. For example, in the parameter "Content," there is an indicator that evaluates whether the destination website provides adequate information on how to navigate within it.

\subsection{Interviews}

Semistructured interviews were conducted with those responsible for eight Spanish tourist destinations and the respective technical personnel responsible for their official websites, specifically the Region of Murcia, City of Madrid, Galicia, Rías Baixas, Sitges, La Rioja, Malaga, and Tarragona. The interviews, which were conducted at the headquarters of the respective organizations between the months of March and July 2014, helped to identify the relationships between the strategic and technical aspects of the website. In them, a set of questions organized into the following five topics were used:

- Organization of the DMO. Policy. Place branding versus Destination branding public diplomacy.

- Branding strategies. Target brand.

- Values and communication. Marketing plan.

- Communication plan.

- Website.

\section{WebSite Canvas Model}

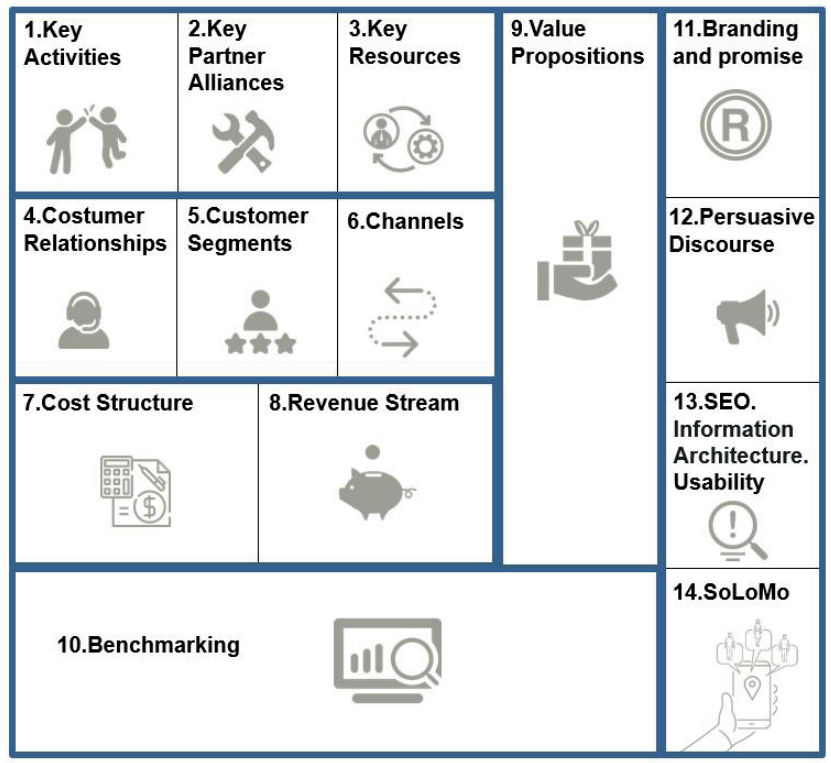

Figure 1. Elements of the Website canvas model

Table 1. Parameters that make up the TWAS

\begin{tabular}{|l|c|}
\hline Parameters & No. of indicators \\
\hline Home pages & 14 \\
\hline Quality and quantity of content & 17 \\
\hline Information architecture & 19 \\
\hline Usability and accessibility & 6 \\
\hline Search engine optimization (SEO) & 8 \\
\hline Distribution or marketing & 6 \\
\hline Languages & 13 \\
\hline Brand treatment & 8 \\
\hline Discursive analysis (text and image) & 12 \\
\hline Interactivity & 8 \\
\hline Social web & 5 \\
\hline Mobile communication & 11 \\
\hline
\end{tabular}


- Social platforms.

- Mobile communication.

To summarize the results, the first column of Table 2 collects the main problems indicated by the interviewees. The second column presents the strategic aspects identified by the WSCM that would be affected. The third column shows the technical parameters of the TWAS system that these problems would affect.

Table 2. Problems detected in the interviews

\begin{tabular}{|c|c|c|}
\hline Problems and concerns detected in the interviews & WSCM area & TWAS parameters \\
\hline Lack of agreed strategic approach & $\begin{array}{l}\text { All areas } \\
\text { Value proposition }\end{array}$ & Not applicable \\
\hline Shortfalls in the identification of audiences & $\begin{array}{l}\text { Customer segments } \\
\text { Customer relations } \\
\text { SoLoMo }\end{array}$ & $\begin{array}{l}\text { Social web } \\
\text { Languages }\end{array}$ \\
\hline $\begin{array}{l}\text { Site maintenance } \\
\text { Updates }\end{array}$ & $\begin{array}{l}\text { Key partners } \\
\text { Key resources }\end{array}$ & Not applicable \\
\hline Poor search engine indexing & SEO & Search Engine Optimization (SEO) \\
\hline Lack of collaboration between sector personnel & $\begin{array}{l}\text { Key partners } \\
\text { Customer segments }\end{array}$ & Distribution or marketing \\
\hline Difficulties in communicating the value proposition & Value proposition & $\begin{array}{l}\text { Discursive analysis } \\
\text { (text and image) }\end{array}$ \\
\hline $\begin{array}{l}\text { Difficulty in defining and communicating the brand (occurring in } \\
\text { the case of consortia, or when the project is the responsibility of } \\
\text { a department of the city council and there is no identifying brand) }\end{array}$ & $\begin{array}{l}\text { Branding and promise } \\
\text { Persuasive discourse }\end{array}$ & Brand treatment \\
\hline Problems in defining the architecture of the site & $\begin{array}{l}\text { SEO } \\
\text { Information Architecture }\end{array}$ & $\begin{array}{l}\text { Information Architecture } \\
\text { Usability and accessibility }\end{array}$ \\
\hline Social networks & SoLoMo & Social web \\
\hline Mobile & SoLoMo & Mobile communication \\
\hline Knowing what the competitors are doing & Benchmarking & Not applicable \\
\hline Lack of commercial focus & $\begin{array}{l}\text { Value proposition } \\
\text { Return on investment } \\
\text { Persuasive discourse }\end{array}$ & Distribution or marketing \\
\hline Lack of indicators of the return of investment & Return of investment & Distribution or marketing \\
\hline Lack of site quality indicators & Strategic quality index & Technical quality index \\
\hline
\end{tabular}

\subsection{Identification of relationships}

To identify the relationships between the strategic aspects and the technical characteristics, a heuristic method was used, as well as interviews with those responsible for the websites. The heuristic identification was based on the previous experience of the authors. The development of more than a dozen systems for evaluating the quality of websites (Pedraza-Jiménez; Codina; Guallar, 2016), as well as the development of more than a hundred websites, have served as the basis for the formulation of this proposal, based on expert observation (Denzin; Lincoln, 2011). This experience was also useful to include a series of solution patterns or recommendations for website problems in the new system.

Specifically, the formalization of the identified relationships was implemented by merging the two mentioned analysis systems, WSCM and TWAS. Table 3 summarizes the correspondence between the strategic sections of the WSCM and the parameters and indicators of a technical, operational, and functional nature of the TWAS.

The table above identifies the strategic and technical sections that influence each other, that is, the aspects that have a direct interdependence, which presumably implies that the problems detected in one of the aspects, be them technical or strategic, would also affect the other related aspects.

For example, if there are deficiencies detected in the evaluation of the parameter "Interactivity," such as a lack of interactive resources, audiovisual material, or guides on the destination, it is difficult for users to recommend and share this information on their social networks, as this parameter is directly related to the strategic section "SoLoMo" (social, local, and mobile). This would be symptomatic of possible shortcomings in the website's social strategy. The same occurs in an analysis of whether to enable user comments, where a negative evaluation of this interactivity indicator would suggest a review of the "SoLoMo" strategy (social, local, and mobile).

Another example of these relationships is that established between the strategic section "Persuasive discourse" of the WSCM system and the "Storytelling" indicator of the "Brand treatment" parameter of the TWAS system. Thus, "Persua- 
Table 3. Correspondence between the parameters of the TWAS and sections of the WSCM

\begin{tabular}{|c|c|c|c|c|c|c|c|c|c|c|c|c|}
\hline $\begin{array}{r}\text { TWAS PARAMETERS } \\
\text { (technical, } \\
\text { operational, } \\
\text { and functional) }\end{array}$ & 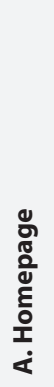 & 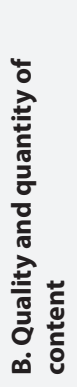 & 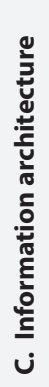 & 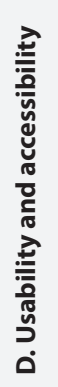 & 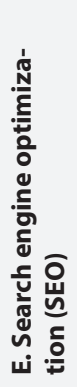 & 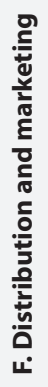 & 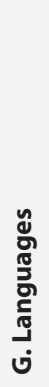 & 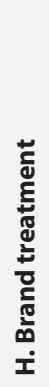 & 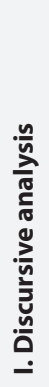 & 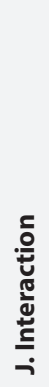 & $\begin{array}{l}\frac{0}{0} \\
\frac{3}{0} \\
\frac{0}{u} \\
\stackrel{\circ}{\circ} \\
\dot{x}\end{array}$ & 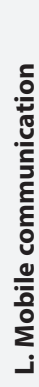 \\
\hline 1. Key activities & $x$ & & & & & $x$ & & & & $x$ & & \\
\hline 2. Key partner alliances & $x$ & & & & & $x$ & & & & $X$ & & \\
\hline 3. Key resources & & & & & & & & & & $X$ & & \\
\hline 4. Customer relationships & $x$ & $x$ & & & & & $x$ & & & $x$ & $x$ & \\
\hline 5. Customer segments & $x$ & $x$ & & & & & $x$ & & & $X$ & & \\
\hline 6. Channels & & & $X$ & $x$ & & & & & & $X$ & $x$ & $\mathrm{X}$ \\
\hline 7. Cost structures & & & & & & $x$ & & & & & & \\
\hline 8. Revenue stream & $x$ & $x$ & & & & $x$ & & & & & & \\
\hline 9. Value proposition & $x$ & $x$ & & & & & & & & $X$ & & \\
\hline \multicolumn{13}{|l|}{ 10. Benchmarking } \\
\hline 11. Branding and promise & & & $x$ & $x$ & & & & $X$ & & $X$ & $x$ & \\
\hline 12. Persuasive discourse & & & $x$ & $x$ & & & & $X$ & $x$ & $X$ & & \\
\hline $\begin{array}{l}\text { 13. SEO, Information architecture, } \\
\text { usability }\end{array}$ & & & $x$ & $x$ & $x$ & $x$ & $x$ & $x$ & & & & \\
\hline 14. SoLoMo & $x$ & & & & & $x$ & & & & $X$ & $x$ & $x$ \\
\hline Total & 7 & 4 & 4 & 4 & 1 & 6 & 3 & 3 & 1 & 10 & 4 & 2 \\
\hline
\end{tabular}

sive discourse" defines which arguments will be used on the web to convince users to act in accordance with the objectives of the organization. Meanwhile, the "Storytelling" indicator assesses whether the actual content on the website conveys the desired story, that is, the arguments previously defined by the organization.

It should be noted that this matrix already reveals the importance of the fact that the technical parameter "Interactivity" includes the strategy of a website. In other words, possible shortcomings or deficiencies in this technical parameter can negatively affect the strategy. Specifically, it could have a negative impact on up to 10 of the 14 sections that define the strategy. Therefore, we can deduce that, if an analysis reveals a low result in the technical evaluation of an interactivity parameter, the strategic component of the web will be critically affected.

Based on these two evaluation methods, the Double-entry analysis system (DEAS) has been formulated, which allows for the evaluation of the quality of a website by starting its evaluation from either its technical or strategic aspects. When the evaluation of a website begins by considering its technical aspects, the method tells us:

1) The quality of these technical aspects, which of them are properly satisfied, and which need to be improved

2) The strategic aspects that are affected by the technical characteristics that present shortcomings

If, on the contrary, the DEAS is activated using the strategic aspects of the website as input, the method indicates:

1) Whether all the strategic aspects necessary for it to successfully fulfill its mission have been considered

2) Which technical aspects are relevant for the strategy to be successful

The tool is thus created to evaluate the overall quality of a website as well as allowing benchmarking studies to be carried out. In addition, this new analysis system incorporates recommendations, guidelines, or patterns of solutions to the problems detected during the evaluation. The objective of the guideline or pattern will be to provide information so that the identified deficiencies can be resolved.

As an example, Table 4 shows part of the application of this system to the official website of the Istanbul tourist destination. The first column presents the strategic aspects (only one is shown in the example), which DEAS relates to the technical aspects that appear in the second and third columns. In the final column, the analysis system offers possible solutions that could be adopted in the event of a poor score. 
Table 4. Example application of DEAS, showing its structure (fragment of application of DEAS to howtoinstanbul.com)

\begin{tabular}{|c|c|c|c|c|}
\hline WSCM & \multicolumn{2}{|c|}{ TWAS parameter and indicator } & Points & Solution/Pattern \\
\hline WSCM element: & TWAS parameter: & & & $\begin{array}{l}\text { Implement an app strategy. } \\
\text { Go to the WSCM's key partners section and check whe- } \\
\text { ther there are partners that could develop this solution. }\end{array}$ \\
\hline SoLoMo & Mobile & $\begin{array}{l}\text { Do the analyzed web pages } \\
\text { have mobile applications? }\end{array}$ & 0 & $\begin{array}{l}\text { Recommendation: Go to WSCM 10. Benchmarking: } \\
\text { Study how competitors apply an app strategy. }\end{array}$ \\
\hline
\end{tabular}

The complete analysis of a website with DEAS would involve, firstly, analyzing all the technical indicators of TWAS and identifying the parameters that do not pass the evaluation. Next, using the DEAS correlation matrix (Table 3), identify the strategic sections of the WSCM that, according to the analysis, are affected. Finally, the system offers recommended solutions for these problems (Table 4).

In summary, when applying the system, the global quality of the website is evaluated, and deficiencies or critical aspects that require intervention are identified, providing the system with patterns or recommendations (Figure 2) to solve them (Terry-González et al., 2016).

\subsection{Quality index}

An index has been devised for the DEAS system, being called the Global web quality index (GWQI). Its creation is based on the indexes used by the two systems described above: the Web quality index (WQI) of the Tourism website assessment system (TWAS) and the Strategic web quality index (SWQI) of the Website canvas model (WSCM).

The WQI was proposed by Fernández-Cavia et al. (2014) to express the quality of the operational and functional aspects of a website through a numerical value. Its calculation takes into account the scores obtained in the indicators of all the TWAS parameters. Specifically, after analyzing a website, this index is obtained by calculating the arithmetic mean of the score obtained for each parameter.

On the other hand, for the global evaluation of the Website canvas model system (Sanabre; Pedraza-Jiménez; Codina, 2018), the Strategic web quality index (SWQI) is used. Its calculation takes into consideration 13 of the 14 sections of the WSCM. This is because the benchmarking section is considered neutral; That is, since it does not evaluate aspects of the website itself but rather studies the strategy of competing sites, it is considered that it should not contribute a score to the index.

Regarding the calculation of the index, its value is obtained quite easily. Basically, a value equal to 0 is assigned to those sections rated as deficient, and a value equal to 1 to each strategic section rated as optimal. The score obtained is divided

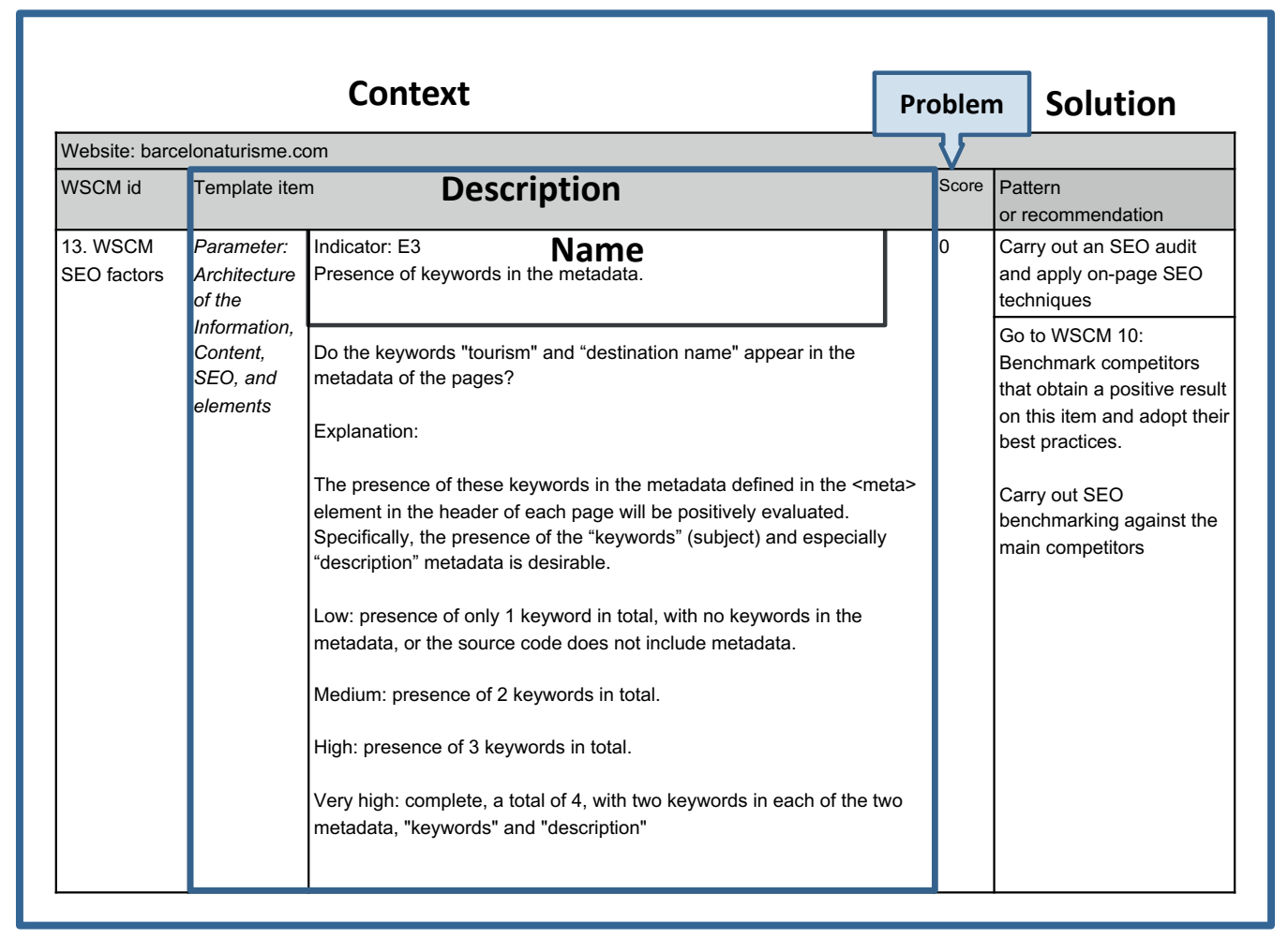

Figure 2. Basic elements of the structure of a pattern in DEAS 
by 13 to yield a normalized value ranging between 0 and 1; For example, if after analyzing a website with the WSCM it were identified that, of its strategic sections, 9 are optimal while 4 have serious deficiencies (Table 5), a score of 9 out of 13 , would be obtained, that is, an SWQI of 0.69 .

Table 5. SWQI application example

\begin{tabular}{|c|c|c|c|}
\hline \multicolumn{4}{|c|}{ Critical areas of intervention for domainX.com } \\
\hline $\begin{array}{c}\text { Tool } \\
\text { of analysis }\end{array}$ & $\begin{array}{c}\text { Critical areas of action } \\
\text { WSCM }\end{array}$ & $\begin{array}{c}\text { Optimal areas } \\
\text { WSCM }\end{array}$ & SWQI \\
\hline DEAS & $\begin{array}{l}\text { 4. Customer relationship } \\
\text { 5. Customer segments } \\
\text { 11. Branding and promise } \\
\text { 12. Persuasive discourse }\end{array}$ & $\begin{array}{l}\text { 1. Key activity } \\
\text { 2. Key partners } \\
\text { 3. Key resources } \\
\text { 6. Channels } \\
\text { 7. Costs Structure } \\
\text { 8. Revenue streams } \\
\text { 9. Value propositions } \\
\text { 13. SEO, Information architecture, usability } \\
\text { 14. SoLoMo } \\
\text { TOTAL: } 9 \text { points }\end{array}$ & 0.69 \\
\hline
\end{tabular}

To calculate the Global web quality index (GWQI), the WQI and SWQI indices must first be obtained. Both of these are then used to formulate the GWQI, considering both the technical functions based on the WQI and the strategic approach based on the SWQI. In this way, the GWQI is obtained as the arithmetic mean of the results obtained by each index. The following table shows a summary of the three indices and the method applied for the calculation (Table 6).

Table 6. Quality indices and the method for their calculation

\begin{tabular}{|l|l|l|}
\multicolumn{1}{|c|}{ Quality index } & \multicolumn{1}{c|}{ Value } & \multicolumn{1}{c|}{ Calculation } \\
\hline $\begin{array}{l}\text { Operational/functional technical Web } \\
\text { quality index }(W Q I)\end{array}$ & $\begin{array}{l}12 \text { technical parameters } \\
127 \text { technical indicators }\end{array}$ & The arithmetic mean of the set of evaluated parameters \\
\hline Strategic web quality index (SWQI) & 13 strategic sections & $\begin{array}{l}\text { The sum of the number of sections rated as optimal by the } \\
\text { WSCM divided by the total number of sections }\end{array}$ \\
\hline Global web quality index (GWQI) & $\begin{array}{l}\text { Operational/functional technical } \\
\text { parameters and website strategy }\end{array}$ & The arithmetic mean of the set of WQI and SWQI \\
\hline
\end{tabular}

As a summary, Figure 3 offers a global vision of the elements that the DEAS analysis system assesses, including the three indices just mentioned.

Finally, in this work a case study method is applied to test the system. Specifically, the DEAS and its GWQI index are used to evaluate the global quality of the official websites of the destinations: Barcelona, Istanbul, London, and Paris. Authors such as Martínez-M (2006), Yin (2009), Campbell (1975), or Barratt, Choi and, Li, (2011) have demonstrated the validity of this method to make analytical generalizations, as would be the case of the analysis system proposed herein.

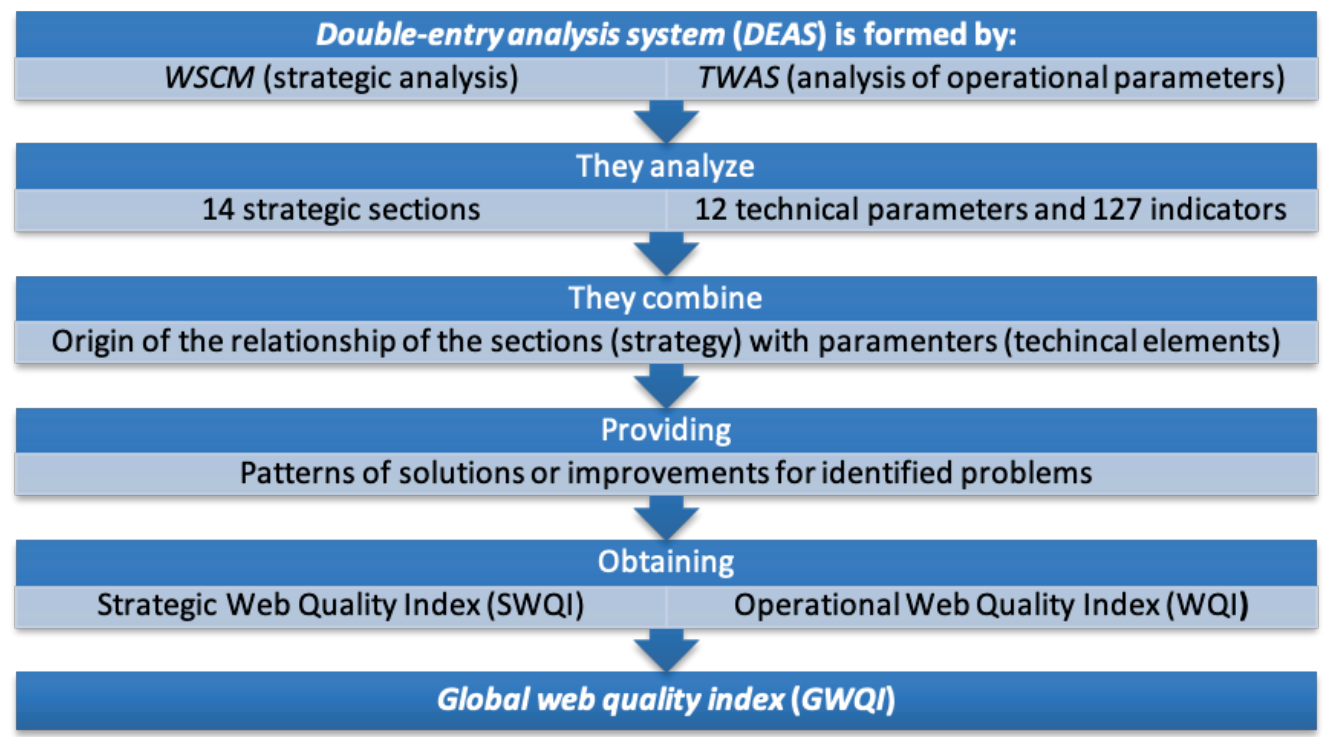

Figure 3. Elements that make up the Double-entry analysis system (DEAS) 


\section{Results}

The results of the case study carried out to apply and test both the analysis system and the proposed index are shown below. Specifically, using the DEAS and its SWQI index, the quality of the official websites of the four most important European tourist destinations has been analyzed and compared (by way of benchmarking), which according to Mastercard global destinations cities index 2016 and the Philips Lighting \& SmartCitiesWorld 2017 are:

London: https://www.visitlondon.com

Paris: https://www.parisinfo.com

Istanbul: http://www.howtoistanbul.com

Barcelona: https://www.barcelonaturisme.com

The evaluation process consisted of first applying the TWAS (fourth quarter of 2016) to the websites of these four tourist destinations. Figure 4 shows and compares the results of these analyses.

As seen in Figure 4, various technical parameters of the websites were identified as being deficient. Specifically, the evaluation revealed that those shown in Table 7 were problematic.

Table 7. TWAS technical parameters with poor evaluation detected for the official websites of the destinations

\begin{tabular}{|l|c|c|c|c|}
\hline \multirow{2}{*}{$\begin{array}{c}\text { TWAS parameters with } \\
\text { deficiencies }\end{array}$} & London & Paris & Destinations that the official website belongs to \\
\cline { 2 - 5 } & & & $\mathrm{X}$ & Barcelona \\
\hline Languages & $\mathrm{X}$ & $\mathrm{X}$ & $\mathrm{X}$ & $\mathrm{X}$ \\
\hline Interaction & $\mathrm{X}$ & & & \\
\hline Brand & & $\mathrm{X}$ & $\mathrm{X}$ & \\
\hline Mobile & & & $\mathrm{X}$ & $\mathrm{X}$ \\
\hline Social web & & & \\
\hline
\end{tabular}

In general terms, these results indicate that the technical quality of the official websites of all the destinations analyzed could be improved, with Istanbul being the one with the greatest number of deficient parameters. Furthermore, they reveal that interacting problems are widespread. Note that the information presented in Table 7 is of a general nature, and it does not show the details of the scores of the indicators of each TWAS parameter. On the contrary, it only specifies the parameters for which problems have been found. This approach was chosen since the aim of this table is to highlight the type of general problems that can be detected by technical evaluation systems. However, Fernández-Cavia, Vinyals-Mirabent, and López-Pérez (2013) present a detailed analysis of destinations using this evaluation system.
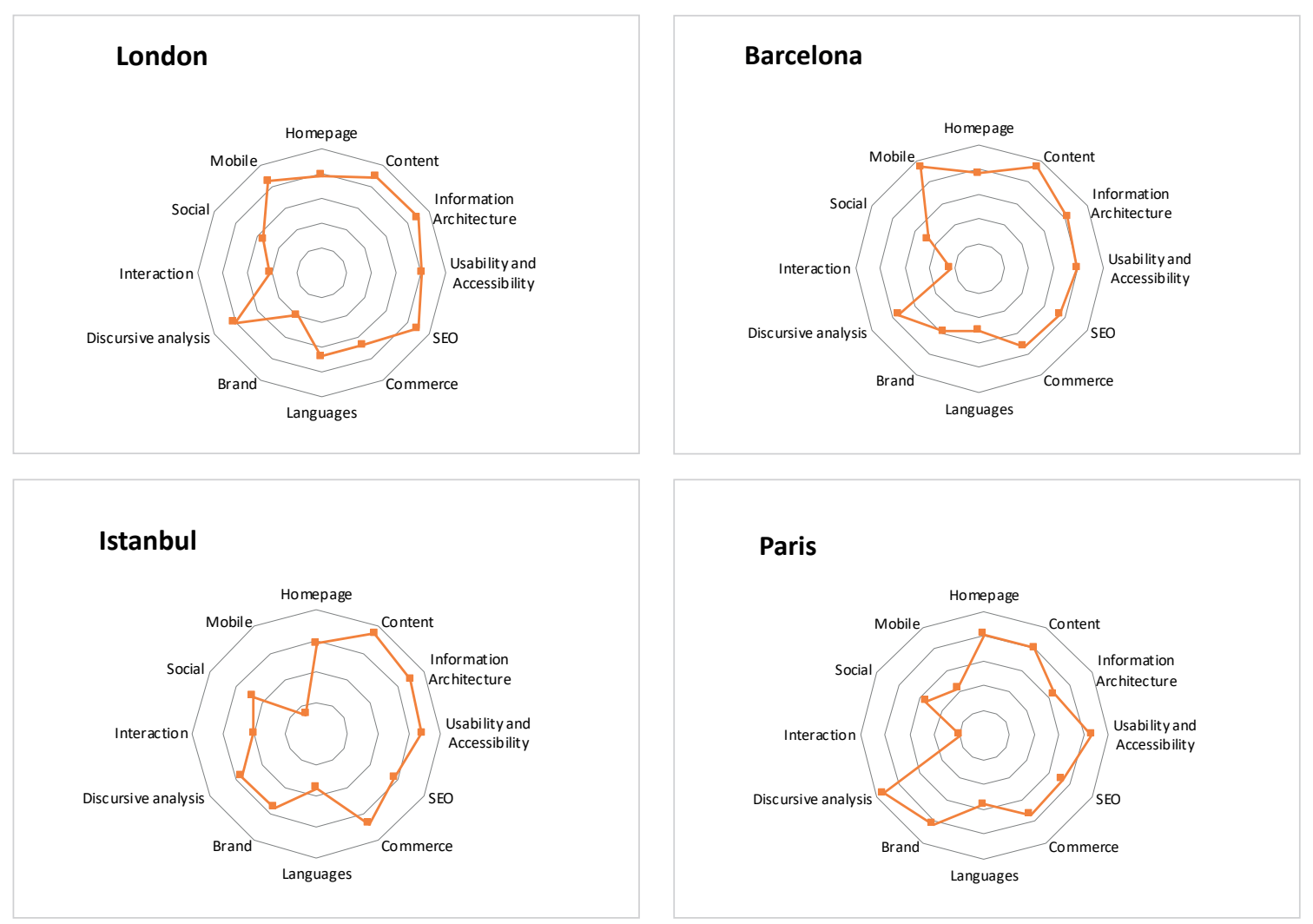

Figure 4. Summary graph of parameters for each destination. Results within the first three inner circles indicate low scores (less than 0.50) 
Having evaluated the technical quality of the four destinations, their strategic quality was evaluated using WSCM. Table 8 illustrates the strategic sections in which the official websites of the destinations had deficiencies (first half of 2017), revealing that they all had them, with the official London website being the one with the best strategic approach.

Table 8. Strategic sections of the WSCM with poor evaluation detected on the official websites of the destinations

\begin{tabular}{|c|c|c|c|c|}
\hline \multirow[t]{2}{*}{ WSCM sections with deficiencies } & \multicolumn{4}{|c|}{ Destinations that the official website belongs to } \\
\hline & London & Paris & Istanbul & Barcelona \\
\hline Key activity & & $X$ & $x$ & $x$ \\
\hline Key partners & & $x$ & $\mathrm{X}$ & $\mathrm{X}$ \\
\hline Key resources & $x$ & $x$ & $\mathrm{x}$ & $x$ \\
\hline Customer relationships & $X$ & $X$ & $X$ & $\mathrm{X}$ \\
\hline Customer segments & & $X$ & $X$ & $X$ \\
\hline Channels & & $X$ & $x$ & $x$ \\
\hline \multicolumn{5}{|l|}{ Structure of costs } \\
\hline \multicolumn{5}{|l|}{ Revenue stream } \\
\hline \multicolumn{5}{|l|}{ Value propositions } \\
\hline Branding and promise & $x$ & $x$ & $x$ & $x$ \\
\hline Persuasive discourse & $x$ & $x$ & $x$ & $x$ \\
\hline SEO, Information architecture, usability & $x$ & $X$ & $x$ & $X$ \\
\hline SoLoMo & $x$ & $x$ & $x$ & $x$ \\
\hline
\end{tabular}

The observation of each table alone does not yield clear conclusions about the functioning and quality of the studied websites. However, their visualization together offers more complete information, seeming to show that the London website is the one with the highest overall quality, in contrast to the Istanbul website, which appears to be the one with the most deficiencies.

This relationship is what DEAS establishes, although at a much deeper level, starting from its relationship matrix. For example, in this evaluation, in the case of Paris.info, DEAS detected that there was a poor interactivity indicator, as it was impossible for users to comment on the content (1) (see Table 9). This indicator affects the general interactivity (2) and, consequently, also negatively affects different aspects of the strategy $(3,4,5$, and 6$)$.

Obviously, identifying such a deficiency in a single indicator as in this example does not imply a negative assessment of a parameter and thereby one or more strategic aspects. Rather, a negative evaluation of various indicators would lead to a negative evaluation of the parameter and impact the strategic aspects of the website.

Table 9. Example of the identification of a deficient indicator using the TWAS for Paris.info and its relationship with the strategic sections of the WSCM

\begin{tabular}{|c|c|c|c|c|}
\hline \multicolumn{5}{|c|}{ Paris.info } \\
\hline WSCM & & TWAS & \multirow{2}{*}{ Score } & \multirow{2}{*}{ Solution/Pattern } \\
\hline Sections affected & Parameters affected & Indicator evaluated as deficient & & \\
\hline $\begin{array}{l}\text { Customer relationships (3) } \\
\text { Customer segments (4) }\end{array}$ & Interactivity (2) & $\begin{array}{l}\text { User comments (1) } \\
\text { Is the user allowed to comment on the }\end{array}$ & 0 & $\begin{array}{l}\text { Implement social media } \\
\text { strategy and allow and } \\
\text { moderate user ratings and } \\
\text { opinions }\end{array}$ \\
\hline $\begin{array}{l}\text { Channels (5) } \\
\text { SoLoMo (6) }\end{array}$ & & authors of the web? & & $\begin{array}{l}\text { Go to WSCM 10: bench- } \\
\text { marking competitors that } \\
\text { obtain a positive result on } \\
\text { this item and adopt their } \\
\text { best practices }\end{array}$ \\
\hline
\end{tabular}

In this way, as seen in this example, the application of the DEAS enables the identification of how these technical problems affect the strategy of the analyzed website. The use of the table of relationships described in the methodology section allows the identification of the following strategic aspects that would be affected by the interaction problems detected:

- Relationship with users/clients: the website's ability to establish fluid communication with potential tourists.

- Customer segments: customers are not well served, especially tourists who are more active and like to comment on 
their trips on social networks.

- Channels: communication with users on social networks and mobile devices is neglected.

- SoLoMo: the socialization of content such as points of interest, museums, shows, etc., on the web or through mobile devices is not promoted.

As a whole, this is an example of the way in which our system interrelates the strategic aspects and technical characteristics of a website. However, to enable a comparison of the results between different websites, it is convenient to use the quality indexes incorporated into the system.

DEAS provides the Global web quality index (GWQI) which, as mentioned in the methodology section, is the arithmetic mean of the WQI (technical quality) and SWQI (strategic quality) indices. The results of the application of these three indices to the four tourist websites analyzed are shown in Figure 5.

The application of the DEAS and GWQI to the websites of each destination reveals the critical areas in which it would be advisable to intervene. The most relevant aspects of each result are detailed below:

For London, visitlondon.com, it is recommended to benchmark competitors and focus efforts on customer relations, branding, and the persuasive discourse.

The Barcelona website, turismebarcelona.com, despite obtaining good technical quality results (69 out of 100), is awarded a bad strategic index (23 out of 100), which generates a low global quality index, revealing the need for a site review. An evaluation of their entire strategy is recommended, placing special emphasis on two aspects that the analysis identifies as critical: the Social web and Interaction.

The official Istanbul website, howtoistanbul.com, should focus its efforts on improving the customer segment section and their relationship with them. It would also be advisable to address improvements in its SoLoMo approach (social, local, and mobile strategy), studying the best practices of its competitors (benchmarking), as well as adopting improvements in the language parameter.

The Paris website, parisinfo.com, presents good technical quality. However, they are advised to review their strategy, as their SWQI is low. The priority aspects for improvement are the architecture used to organize the content and the interaction options.

\section{Discussion}

According to Cheng et al. (2013), it is very important that a website be of high quality, since it transmits to its users the values and corporate qualities of the institution it represents. Even so, and despite the various problems involved in managing a site (Rodríguez-Martínez; Codina; Pedraza-Jiménez, 2010), organizations often do not establish quality review systems. The consequence is that they end up having websites that do not provide any differentiation with respect to other institutions or companies and that, in addition, do not respond to their institutional needs. This is probably due to the fact that their development is started without having previously carried out an adequate strategic design.

In this work, a system that takes into account strategic aspects is proposed for evaluating web quality. The system has been tested in real cases and, therefore, is very practical. This differentiates it from other existing systems and models for evaluating web quality (some of which are cited at the beginning of this article) and which are characterized by being mainly theoretical contributions.

Likewise, unlike other proposals, DEAS is a modular evaluation system that allows a comprehensive evaluation. There are many systems for evaluating the technical characteristics of a website. Also, although they are not so numerous, various evaluation systems have been designed to address strategic aspects at greater or less depth. However, there are very few systems - and those that exist are specialized to very specific aspects, as pointed out by Hernández, Jiménez, and Martín (2009) -that, like DEAS, enable the joint evaluation, and even relation, of the technical characteristics and strategic aspects of the website. This is probably one of the main advantages of the proposed approach.

Finally, it is important to highlight the modular nature of this evaluation method, which makes it a flexible system, capable of incorporating and relating different analysis systems to comprehensively evaluate the quality of websites; That is, although in this work DEAS has been presented and tested by incorporating the TWAS and WSCM systems, the method has been designed such that the technical characteristics of a website could be evaluated using analysis systems other than TWAS. For example, if one wanted to evaluate the quality of an e-commerce website, it would be sufficient to 
replace the TWAS system in DEAS with an evaluation system specialized in e-commerce, such as that of Roig and Pedraza-Jiménez (2016). This is one of the functions that increases the potential of this method.

Despite the large volume of work on quality and evaluation systems, especially oriented towards tourism portals, e-commerce, governments, banking (Wątróbski et al., 2016), or cybermedia (Ochoa-Urrego, 2019), the novelty of our model is that it complements and extends current evaluation systems to improve the strategic component of websites. It is an accessible and practical system for all types of organizations, regardless of their size.

\section{Conclusions}

This work presents a new system, DEAS, for the comprehensive evaluation of websites. The results of its application show that it is effective for:

1) Defining and analyzing strategy

It helps those responsible for a website to define an appropriate strategy to achieve their objectives. In addition, it identifies which technical aspects can affect the strategy and, consequently, the success of its mission.

2) Evaluating technical aspects

It evaluates the technical aspects of the website in order to detect possible problems that affect its proper functioning.

It can anticipate what impact a technical problem will have on the site's strategy and mission. It also indicates to those responsible for the technical aspects which areas must be strengthened to improve specific features of their strategy.

On the other hand, this article also proposes a new index for the evaluation of the global quality of websites, called the GWQI. This index allows the use of DEAS to carry out benchmarking studies, that is, to carry out quality comparisons between competing websites.

Furthermore, the objective of testing DEAS and GWQI has been achieved by evaluating the official websites of the four most visited destinations in Europe, confirming that their technical quality is insufficient to achieve their objectives. Moreover, a website may have great technical quality but still not satisfy the objectives of its managers at all.

In this way, based on the analyzed case studies, this method reveals that "interactivity" is a technical parameter that has a great impact on the strategic aspects of a website and, therefore, on its overall quality and value as perceived by the users (Abdullah; Jayaram; Kamal, 2016). This finding will be the subject of further analysis and study by the authors in future work.

Finally, as future work, in addition to applying it in other sectors, the DEAS system will be tested by merging and relating new analysis systems. Specifically, it is of great interest to integrate DEAS into the system for the analysis of cybermedia (Pedraza-Jiménez; Codina; Guallar, 2016), e-commerce analysis systems (Roig; Pedraza-Jiménez, 2016), and the integrated model for the analysis of information aggregators on mobile devices (Figueroa-Encina, 2018).

\section{References}

Abdullah, Dahlan; Jayaraman, K.; Kamal, Saiful B. M. (2016). "A conceptual model of interactive hotel website: The role of perceived website interactivity and customer perceived value toward website revisit intention". Procedia economics and finance, v. 37, pp. 170-175.

https://doi.org/10.1016/S2212-5671(16)30109-5

Auer, Christoph; Petrovic, Otto (2004). "E-measurement: an integrated methodology for measuring the performance of e-services". International journal of electronic business, v. 2, n. 6, p. 583-602. https://doi.org/10.1504/IJEB.2004.006127

Barratt, Mark; Choi, Thomas Y.; Li, Mei (2011). “Qualitative case studies in operations of management: Trends, research outcomes, and future research implications". Journal operations management, v. 29, n. 4, pp. 329-342.

https://doi.org/10.1016/j.jom.2010.06.002

Buhalis, Dimitrios; Law, Rob (2008). "Progress in information technology and tourism management: 20 years on and 10 years after the Internet - The state of eTourism research". Tourism management, v. 29, n. 4, pp. 609-623.

https://doi.org/10.1016/j.tourman.2008.01.005

Campbell, Donald T. (1975). "Degrees of freedom and the case study". Comparative political studies, v. 8, n. 1, pp. $178-191$.

Cheng, Qiang; Du, Fei; Wang, Xin; Wang, Yutao (2013). “Are investors' corporate site visits informative?”. Research collection school of accountancy.

https://ink.library.smu.edu.sg/soa_research/1095

Chias, Josep (2005). El negocio de la felicidad. Desarrollo y marketing turistico de países, regiones, ciudades y lugares. Madrid: Prentice Hall. ISBN: 8420544043 
Cho, Mi-Hea; Sung, Heidi H. (2012). "Travel destination websites: Cross-cultural effects on perceived information value and performance evaluation". Journal of travel \& tourism marketing, v. 29, n. 3, pp. 221-241.

https://doi.org/10.1080/10548408.2012.666169

Codina, Lluís (2000). "Evaluación de recursos digitales en línea: conceptos, indicadores y métodos". Revista española de documentación científica, v. 23, n. 1, pp. 9-44.

https://doi.org/10.3989/redc.2000.v23.i1.315

Codina, Lluís (2006). Metodología de análisis y evaluación de recursos digitales en línea. Área de Biblioteconomía y Documentación, Departamento de Periodismo y Comunicación Audiovisual. Barcelona: UPF.

https://www.lluiscodina.com/wp-content/uploads/metodos2006.doc

Contreras, Ruth-Sofía (2010). Disseny per a web. En: Navarro, Héctor (ed.). Disseny gràfic i disseny web. Breus lliçons sobre història, teoria i pràctica, pp. 213-250. Vic: Eumo. ISBN: 9788497663489

Dalton, Richard (2007). The forces of user experience.

http://mauvyrusset.com/2007/06/16/the-forces-of-user-experience

Dedeke, Adenekan-Nick (2016). "Travel web-site design: Information task-fit, service quality and purchase intention". Tourism management, v. 54, pp. 541-554.

https://doi.org/10.1016/j.tourman.2016.01.001

Denzin, Norman K.; Lincoln, Yvonna S. (2011). The Sage handbook of qualitative research. Thousand Oaks, California: Sage. ISBN: 1412974178

Dickinger, Astrid; Stangl, Brigitte (2013). "Website performance and behavioral consequences: A formative measurement approach". Journal of business research, v. 66, n. 6, pp. 771-777.

https://doi.org/10.1016/j.jbusres.2011.09.017

European Commission (2017). Management and content provision for ICT and tourism business support portal. https://ec.europa.eu/docsroom/documents/24262/attachments/1/trans/ations/en/renditions/native

Fernández-Cavia, José; Díaz-Luque, Pablo; Huertas, Assumpció; Rovira, Cristòfol; Pedraza-Jiménez, Rafael; Sicilia, María; Gómez-Puertas, Lorena; Míguez-González, María-Isabel (2013). “Marcas de destino y evaluación de sitios web: una metodología de investigación”. Revista latina de comunicación social, n. 68, v. 5, pp. 622-638.

https://doi.org/10.4185/RLCS-2013-993

Fernández-Cavia, José; Rovira, Cristòfol; Díaz-Luque, Pablo; Cavaller, Víctor (2014). "Web quality index (WQI) for official tourist destination websites. Proposal for an assessment system". Tourism management perspectives, v. 9, pp. 5-13. https://doi.org/10.1016/j.tmp.2013.10.003

Fernández-Cavia, José; Vinyals-Mirabent, Sara; López-Pérez, Marina (2013). “Calidad de los sitios web turísticos oficiales de las comunidades autónomas españolas". BiD: textos universitaris de biblioteconomia i documentació, n. 31. https://doi.org/10.1344/BiD2014.31.7

Figueroa-Encina, Patricio-Alberto (2018). El ecosistema móvil y las noticias en la era de las plataformas digitales. Análisis heurístico de aplicaciones móviles y agregadores de noticia. Tesis doctoral. Barcelona: Universitat Pompeu Fabra.

Fisher, Julie; Craig, Annemieke; Bentley, John (2007). “Moving from a web presence to e-commerce: The importance of a business-web strategy for small-business owners". Electronic markets, v. 17, n. 4, pp. 253-262.

https://doi.org/10.1080/10196780701635864

Fogli, Daniela; Guida, Giovanni (2015). "A practical approach to the assessment of quality in use of corporate web sites". Journal of systems and software, v. 99, pp. 52-65.

https://doi.org/10.1016/j.jss.2014.09.006

Fogli, Daniela; Guida, Giovanni (2018). "Evaluating quality in use of corporate web sites: An empirical investigation". ACM Transactions on the web (TWEB), v. 12, n. 3, pp. 1-35.

https://doi.org/10.1145/3184646

Frías, Dolores-María; Rodríguez, Miguel A.; Castañeda, J. Alberto (2008). “Internet vs. travel agencies on pre-visit destination image formation: An information processing view". Tourism management, v. 29, n. 1, pp. 163-179.

https://doi.org/10.1016/j.tourman.2007.02.020

Garrett, Jesse-James (2011). The elements of user experience: user-centered design for the web and beyond ( $2^{\text {nd }}$ ed.). San Francisco: New Riders. ISBN: 032168368

González-López, Óscar R.; Bañegil-Palacios, Tomás M.; Buenadicha-Mateos, María (2013). “El índice cuantitativo de calidad web como instrumento objetivo de medición de la calidad de sitios web corporativos". Investigaciones europeas de dirección y economía de la empresa, v. 19, n. 1, pp. 16-30.

https://doi.org/10.1016/j.iedee.2012.07.004 
Guallar, Javier; Abadal, Ernest; Codina, Lluís (2013). "Sistema de análisis de hemerotecas de prensa digital”. Trípodos, n. 31, pp. 37-64.

http://www.tripodos.com/index.php/Facultat_Comunicacio_Blanquerna/article/view/37/22

Hernández, Blanca; Jiménez, Julio; Martín, M. José (2009). "Key website factors in e-business strategy". International journal of information management, v. 29, n. 5, pp. 362-371.

https://doi.org/10.1016/j.ijinfomgt.2008.12.006

Inversini, Alessandro; Cantoni, Lorenzo; De-Pietro, Marianna (2014). "Destination online communication: Why less is sometimes more. A study of online communications of English destinations". Journal of travel \& tourism marketing, v. 31, n. 5, pp. 563-575.

https://doi.org/10.1080/10548408.2014.883949

Ip, Crystal; Law, Rob; Lee, Hee-Andy (2011). "A review of website evaluation studies in the tourism and hospitality field from 1996 to 2009". International journal of tourism research, v. 13, n. 3, pp. 234-265.

https://doi.org/10.1002/jtr.815

Jiménez-Iglesias, Lucía; Pérez-Montoro, Mario; Sánchez-Gómez, Lydia (2017). “Diseño de información digital: revisión y clasificación de indicadores heurísticos para contenidos web". El profesional de la información, v. 26, n. 6, pp. 1029-1046. https://doi.org/10.3145/epi.2017.nov.03

Kang, Yong-Soon; Kim, Yong-Jin (2006). “Do visitors' interest level and perceived quantity of web page content matter in shaping the attitude toward a web site?". Decision support systems, v. 42, n. 2, pp. 1187-1202.

https://doi.org/10.1016/j.dss.2005.10.004

Kaur, Satinder; Gupta, Sunil-Kumar (2014). "Key aspects to evaluate the performance of a commercial website". International journal of computer applications, v. 1, n. 1, pp. 1-5.

https://www.ijcaonline.org/proceedings/icacea/number1/15608-1422

Law, Rob; Bai, Billy (2008). "How do the preferences of online buyers and browsers differ on the design and content of travel websites?". International journal of contemporary hospitality management, v. 20, n. 4, pp. 388-400.

https://doi.org/10.1108/09596110810873507

Law, Rob; Qi, Shanshan; Buhalis, Dimitrios (2010). "Progress in tourism management: A review of website evaluation in tourism research". Tourism management, v. 31, n. 3, pp. 297-313.

https://doi.org/10.1016/j.tourman.2009.11.007

Lee, Woojin; Gretzel, Ulrike (2012). “Designing persuasive destination websites: A mental imagery processing perspective". Tourism management, v. 33, n. 5, pp. 1270-1280.

https://doi.org/10.1016/j.tourman.2011.10.012

Li, Xu; Wang, Youcheng (2010). “Evaluating the effectiveness of destination marketing organisations' websites: evidence from China". International journal of tourism research, v. 12, n. 5, pp. 536-549.

https://doi.org/10.1002/jtr. 772

Lopezosa, Carlos; Codina, Lluís; Rovira, Cristòfol (2019). "Visibilidad web de portales de televisión y radio en España: ¿qué medios llevan a cabo un mejor posicionamiento en buscadores?”. Serie DigiDoc-EPI, n. 4. Barcelona: Universitat Pompeu Fabra, Departamento de Comunicación; Ediciones Profesionales de la Información SL. ISBN: 9788409077168

Luna-Nevarez, Cuauhtemoc; Hyman, Michael R. (2012). “Common practices in destination website design”. Journal of destination marketing \& management, v. 1, n. 1-2, pp. 94-106.

https://doi.org/10.1016/j.jdmm.2012.08.002

Mandal, Santanu; Roy, Souvik; Raju, Amar G. (2017). "Exploring the role of website attractiveness in travel and tourism: empirical evidence from the tourism industry in India". Tourism planning \& development, v. 14, n. 1, pp. $110-134$. https://doi.org/10.1080/21568316.2016.1192058

Martínez-M., Miguel (2006). "La investigación cualitativa (síntesis conceptual)”. Revista de investigación en psicología v. 9, n. 1, pp. 123-146. https://doi.org/10.15381/rinvp.v9i1.4033

Mastercard global destinations cities index (2016). https://newsroom.mastercard.com/wp-content/uploads/2016/09/FINAL-Global-Destination-Cities-Index-Report.pdf

Morrison, Alastair M. (2013). Marketing and managing tourism destinations. New York: Routledge. ISBN: 0415672503

Nielsen, Jakob (1994). "Usability inspection methods". In: Conference companion on Human factors in computing systems. Association for Computing Machinery 1994. New York, NY, USA. pp. 413-414.

https://doi.org/10.1145/259963.260531 
Nielsen, Jakob (1999). Designing web usability: The practice of simplicity. New Riders Publishing. ISBN: 9781562058104

Ochoa-Urrego, Rafael (2019). “Índice de accesibilidad para cibermedios mexicanos”. Revista española de documentación científica, v. 42, n. 3, e244.

https://doi.org/10.3989/redc.2019.3.1541

Olsen, George (2003). "Approaches to user experience". Boxes and arrows, v. 10.

http://boxesandarrows.com/files/banda/expanding_the_approaches_to_user_experience/uxapproachesmodel.pdf

Opoku, Robert (2009). "Mapping destination personality in cyberspace: An evaluation of country web sites using correspondence analysis". Journal of internet commerce, v. 8, n. 1-2, pp. 70-87.

https://doi.org/10.1080/15332860903182438

Opoku, Robert; Abratt, Russell; Pitt, Leyland (2006). "Communicating brand personality: Are the websites doing the talking for the top South African business schools?". Journal of brand management, v. 14, n. 1, pp. 20-39.

https://doi.org/10.1057/palgrave.bm.2550052

Osterwalder, Alexander; Pigneur, Yves (2010). Business model generation: A handbook for visionaries, game changers, and challengers. New Jersey: John Wiley \& Sons. ISBN: 0470876417

Park, Young A.; Gretzel, Ulrike (2007). "Success factors for destination marketing web sites: A qualitative meta-analysis". Journal of travel research, v. 46, n. 1, pp. 46-63.

httpd://doi.org/10.1177/0047287507302381

Patkose, Margaret; Stokes, Andrea M.; Cook, Suzanne D. (2004). Travelers' use of internet. Washington: Travel Industry Association of America.

Pedraza-Jiménez, Rafael; Blanco, Saúl; Codina, Lluís; Cavaller, Víctor (2013). “Diseño conceptual y especificación de requerimientos para el desarrollo y rediseño de sitios web". El profesional de la información, v. 22, n. 1, pp. 74-79.

https://doi.org/10.3145/epi.2013.ene.10

Pedraza-Jiménez, Rafael; Codina, Lluís; Guallar, Javier (2016). Calidad en sitios web: método de análisis general, e-commerce, imágenes, hemerotecas y turismo. Barcelona: Editorial UOC. ISBN: 9788490644874

Pérez-Montoro, Mario; Codina, Lluís (2010). "Software de prototipado para la arquitectura de la información: funcionalidad y evaluación". El profesional de la información, v. 19, n. 4, pp. 417-424.

https://doi.org/10.3145/epi.2010.jul.12

Philips Lighting \& SmartCitiesWorld (2017).

http://www.lighting.philips.com/main/inspiration/smart-cities/smart-city-trends

Pike, Steven (2012). Destination marketing. An integrated marketing communication approach (2 ${ }^{\text {nd }}$ ed.). New York: Routledge. ISBN: 9780750686495

Piñeiro-Naval, Valeriano; Igartua, Juan-José; Marañón, Felipe (2017). “El diseño de las sedes web municipales de España. Una propuesta metodológica para su análisis". Revista española de documentación científica, v. 40, n. 1, e164. https://doi.org/10.3989/redc.2017.1.1368

Qayyum, Sehar; Rafiq, Samiya (2016). "Website design usability issues faced by the user in Pakistan”. Computer engineering and intelligent systems, v. 7, n. 9, pp. 14-17.

https://iiste.org/Journals/index.php/CEIS/article/view/32859

Rodríguez-Martínez, Ruth; Codina, Lluís; Pedraza-Jiménez, Rafael (2010). “Cibermedios y web 2.0: modelo de análisis y resultados de aplicación". El profesional de la información, n. 19, v. 1, pp. 35-44.

https://doi.org/10.3145/epi.2010.ene.05

Rodríguez-Molina, Miguel A.; Frías-Jamilena, Dolores-María; Castañeda-García, José-Alberto (2015). “The contribution of website design to the generation of tourist destination image: The moderating effect of involvement". Tourism management, v. 47, pp. 303-317.

https://doi.org/10.1016/j.tourman.2014.10.001

Roig, Noemí; Pedraza-Jiménez, Rafael (2016). “Comercio electrónico”. En: Pedraza-Jiménez, Rafael; Codina, Lluís; Guallar, Javier (coords.). Calidad en sitios web. Método de análisis general, e-commerce, imágenes, hemerotecas y turismo. Colección EPI Scholar. Barcelona: Editorial UOC. ISBN: 9788490644874

Rosenfeld, Louis; Morville, Peter (2006). Information architecture for the world wide web (3a ed.). Sebastopol: O'Reilly Media, Inc., 264 pp. ISBN: 0596527349

Rovira, Cristòfol; Fernández-Cavia, José; Pedraza-Jiménez, Rafael; Huertas, Assumpció (2010). “Posicionamiento en buscadores de las webs oficiales de capitales de provincia españolas". El profesional de la información, v. 19, n. 3, pp. $277-283$. http://doi.org/10.3145/epi.2010.may.08 
Sanabre, Carles (2015). “Un modelo para el análisis y concepción de sitios web: El WebSite Canvas Model aplicado a Eldiario.es". Hipertext.net, Anuario académico sobre documentación digital y comunicación interactiva, v. 13. http://doi.org/10.2436/20.8050.01.20

Sanabre, Carles; Pedraza-Jiménez, Rafael; Codina, Lluís (2018). “WebSite Canvas Model: propuesta de un modelo visual para la ideación estratégica de sitios web". Revista española de documentación científica, v. 41, n. 4, pp. 221. https://doi.org/10.3989/redc.2018.4.1542

Sanabre, Carles; Vinyals-Mirabent, Sara; Pedraza-Jiménez, Rafael (2019). “Calidad de los sitios web turísticos. El caso del DTI Barcelona". ARA: Revista de investigación en turismo, v. 9, n. 1, pp. 7-17.

http://revistes.ub.edu/index.php/ara/article/view/27970/29552

Standing, Craig; Tang-Taye, Jean-Pierre; Boyer, Michel (2014). "The impact of the internet in travel and tourism: A research review 2001-2010". Journal of travel \& tourism marketing, v. 3, n. 1, pp. 82-113. https://doi.org/10.1080/10548408.2014.861724

Sun, Sunny; Fong, Davis-Ka-Chio; Law, Rob; He, Shan (2017). "An updated comprehensive review of website evaluation studies in hospitality and tourism". International journal of contemporary hospitality management, v. 29, n. 1, pp. 355-373. https://doi.org/10.1108/IJCHM-12-2015-0736

Tang, Lian-Rebecca; Jang, Soocheong (2011). "Investigating the routes of communication on destination websites". Journal of travel research, v. 51, n. 1, pp. 94-108.

https://doi.org/10.1177/0047287510394196

Tang, Liang-Rebeca; Jang, Soocheong; Morrison, Alastair (2012). "Dual-route communication of destination websites". Tourism management, v. 33, n. 1, pp. 38-49. https://doi.org/10.1016/j.tourman.2011.01.021

Terry-González, Yasirys; Stable-Vilches, Osvaldo E.; Pérez-González, Pedro; Fernández-Cabrera, Claudio (2016). “Gestión de patrones de diseño de recursos educativos en Croda 3.0". En: XI Congreso de tecnología en educación y educación en tecnología. ISBN: 9789873977305

Therkelsen, Anette (2015). "Rethinking place brand communication: from product-oriented monologue to consumer-engaging dialog". In: Kavaratzis, M.; Warnaby, G.; Ashworth, G. J. (eds.). Rethinking place branding comprehensive brand development for cities and regions, pp. 159-173. London: Springer. ISBN: 9783319124247

Tran, Dieu-Thi; Yan, Zhiming (2014) “Website evaluation for destinations: The application of an extended theoretical framework". In: Egger, R.; Maurer, C. (eds.). Iscontour 2014 Tourism research perspectives - Proceedings of the international student conference in tourism research,, pp. 137-147. Krems: BoD - Books on Demand.

Vinyals-Mirabent, Sara (2014). "Branding and website communication: a long road ahead". In: Egger, R.; Maurer, C. (eds.). Iscontour 2014 Tourism research perspectives - Proceedings of the international student conference in tourism research, pp. 272-280. Krems: BoD - Books on Demand.

Wątróbski, Jarosław; Ziemba, Paweł; Jankowski, Jarosław; Wolski, Waldemar (2016). "Pequal- E-commerce websites quality evaluation methodology". In: Federated conference on computer science and information systems (FedCSIS), IEEE, pp. 1317-1327. https://doi.org/10.15439/2016F469

Xanthidis, Dimitrios; Argyrides, Paris; Nicholas, David (2009). "Web site evaluation index: a systematic methodology and a metric system for the assessment of the quality of web sites". In: WSEAS international conference. proceedings. Mathematics and computers in science and engineering, n. 8. World Scientific and Engineering Academy and Society.

Xiang, Zheng; Wang, Dan; O'Leary, Joseph T.; Fesenmaier, Daniel R. (2014). “Adapting to the Internet: Trends in travellers' use of the web for trip planning". Journal of travel research, v. 54, n. 4, pp. 1-17. https://doi.org/10.1177/0047287514522883

Yin, Robert K. (2009). Doing case study research, $4^{\text {th }}$ ed. Thousand Oaks, CA: Sage. ISBN: 1412960991 